\title{
Network Information Policy and Legal System Construction in Japan and Its Implication for China
}

\author{
Jia-hao YANG ${ }^{1}$ and Xiang-yang $\mathrm{HU}^{1,}$ * \\ ${ }^{1}$ Zhongnan University of Economics and Law, College of Criminal Justice, Wuhan \\ 430073, China \\ ${ }^{*}$ Corresponding author
}

Keywords: Network information problem, Policy and legal system, Construction, China.

\begin{abstract}
By making full use of the resources of literature and data, the status of network information policy and legal system in Japan was disclosed, the outburst features and rules were summarized, and major differences between China and Japan were found. Especially, characteristics of strategic objective, management system, emphasis and form of network information policy and law in Japan were analyzed. The work demonstrated that focusing on study of law and theory of network information resources, its lead to the development and application of new technology, self-construction of network information law and policy system as well as highlighting strategic significance of its construction are implication for our country. The research provided reliable reference for governments at all levels to formulate network information policy and law.
\end{abstract}

\section{Introduction}

With the quick development of network information, various network information problems, for example network infringement [1], information pollution, virus attack, network crime and other problems are emerging coinstantaneous. If the problems are not controlled effectively, it will cause severe damage on political, economical, cultural, educational and scientific research and other aspects of state. This will also retard the progress of society in China. In this paper I try to summarize the characteristics and tendencies of network information policy and legal system in developed countries such Japan. Based upon its implication to construction of corresponding policy and legal system in many aspects of network information, I present my point of view as well as some helpful discussion in order to solve the problem further of network information.

\section{Analysis on Status and Characteristic of Network information Policy and Law Construction in Japan}

\section{Status of Japanese Network Information Policy and Law}

The computer technology, network information industry and technology and economy of Japan are in a world-leading position. Japan is one of the earlier countries that make network information policy and law. The development of Japanese network information policy and law can be segmented into three stages [2]. (i) The very beginning of establishment of Japanese network information system (i. e. during the late 50's to the early 70's in last century): in this stage, the computer was established as the major direction of network information policy, and Japanese government released a 
series of policy documents, such as Promotion of 10 Year's Target: Comprehensive Policy of Science in Japan, Development of Supercomputer, Basic Policies for Circulation of Science Information, etc. (ii) All-round development stage of information industry (during the 70's to the 80's). The significant direction is to promote the construction of database and information network. Therefore, a slew of laws and policies, for example The Joint Development Guidelines of Electronic Computer, The Temporary Measures Law for the Promotion of the Machinery Industry and the Special Tool Industry, Association of Information Processing Revitalization and Laws, Promotion of Information Processing and Laws, Industrial System of Software Production in Japan, Intermediate Report on the Database had been issued. (iii) In line with international standards and communication (since mid-and-late 80's). The Japanese government put forward a lot of measures of creating English database and strengthening information cooperation with foreign countries. The Fundamental Law of Science and Technology and the Basic Plan of Science and Technology were established in Japan in 1995 and 1996, respectively and the second Basic Plan for Science and Technology R\&D was established in April, 2001. (iv)With the development of Internet, the harmful information, for example libel, slander, invasion of privacy and infringement of intellectual property on internet has triggered a lot of social problems and even threats national security. The Japanese government begins to widely monitor network information to maintain the national safety of network. The Japan's parliament has published series of network laws, for example Measures for the Administration of Internet Specific E-mail Services, which demands malicious email sender to inform receiver information of his name, and mustn't send malicious email to the clients that show utter refusal [3]. In 2014, Basic Act on Cybersecurity was passed to resolve problems of cyber-attack and cybercrimes, although it may be partly violate the Article 21 of the Japanese Constitution (No censorship shall be maintained, nor shall the secrecy of any means of communication be violated) and Article 4 of Japan's Telecommunications Business Law(The secrecy of communications being handled by a telecommunications carrier shall not be violated).

\section{Characteristics of Network Information Law and Policy System in Japan}

Japanese is the earliest country in the world that regards information resource as emblem of mammon and takes active part in information manipulation. It is a model which builds country by science and information. In order to guarantee the scientificity, predictability and validity of the law and policy, Japan Government strengthens the basic research on management law and policy of information resource, explores the ways for information law and policy to play their role in the network environment and studies the construction and content of law and policy system. Furthermore, it predicts the technical, economical and other social factors that influence the development of law and policy, investigates the status of judicial, legislative and law enforcement in Japan. Then it put forward suggestion for making network information management law and policy. Japanese government introduces policy innovations in science and technology. This policy innovation pursues three directions: from bottom-up to top-down, from input-focus to policy-cycle-type, and from science and technology policy to innovation policy. The core of these policies is concentrating on research of network information resource development, application, management as well as law and policy. In line with characteristics of times, the management policy and legal system of network information resource are regulated continuously to promote the effective use of 
information resource, develop and foster information industry. The construction characteristics of law and policy are as follows.

(a) The Information Society is introduced as major theme to promote the full application of IT and network technology, support the perfection of application-oriented network infrastructure along with construction of new network information society in view of overall goals. By way of establishing and practicing law and policies of electronic and digital society, economy, culture and education, it narrows the gap between the United States and the European Union.

(b) The chief characteristics are to adopt policy of centralized unified management and decentralized development in the perspective of management system. In practicing and making the law and policy of network information, the government strengthens support and plays a leading role. Information Technology Industry Council and its branch along with industry organization play supporting role.

(c) There are special government agencies of Japan Congress, Science and Technology Agency, METI and MITI together with Information Technology Industry Council and its special branches. In addition, there are lots of nongovernmental information industry associations and organizations, for example Association of Information Processing Revitalization, Association of Information Service Industry, Japan PC Software Association and SIGMA. These industrial associations and organizations play active role in enacting industry standards and regulations, facilitating communication between government and information enterprises, maintaining the industry interests, strengthening cooperation of different industry and ensuring industry self-regulation.

(d) Information policy consultation and investigation mechanism of industry-government-university integration together with multiple-in-one policy and law research system are built up in the formation mechanism of network information policy and law. Japanese government set up relatively stable research, consultation and decision-making mechanisms of information policy and law [3]. Some of the major information policy and law are studied by consultation organization of information policy under the Prime Minister House and the relevant ministries and agencies. Besides, the information policies are discussed and modified at regular intervals. It thus ensures the information policy can be regulated according to the situation at that time.

(e) Japan government pays high attention to national cybersecurity and emergency response of network information resource in aspects of emphasis on network information law and policy as the realistic threats are increasing rapidly,. The NISC (National Information Security Center) was established in 2000 as the Information security Measures Promotion Office, but in 2005, after restructuring, it became the NISC. It is part of the Cabinet Secretariat. The head of NISC has dual responsibilities of physical security and cybersecurity. The network information policy and legal system are decided by the Cyber Security Strategy Headquarters (CSSH), which is chaired by a Chief Cabinet Secretary and involved many vital ministers. Under the CSSH's formal direction and in cooperation with the NISC, policies are carried out by the ministries and agencies.

\section{Experience of Japanese Law and Policy System Construction}

(a) Attach great importance to guidance and development of network information technology, and actively encourage and promote development of information network infrastructure and technology. 
Japan government pays attention to the technical standard of various network communications so as to promote the development of network communication technical production and service, thus guarantee its leading position in domestic and foreign markets. On the other hand, it releases all kinds of law and regulations to solve new problems emerging from information network in order to consolidate its position of information technology power.

(b) Highlight government's leading role in network information law and policies, and pay attention to participation of groups, industrial associations and other agencies.

(c) Insist on encouraging and promoting development of network information, industrial self-regulation, user responsible for oneself and legislative principle of strict network management.

(d) Pay high attention to the development and utilization of network information resource, and lay emphasis on drawing on foreign network information resource.

(e) Place great emphasis on guidance and regulation of network information market and service.

(f) Emphasize on the interrelation of network information and economy, an consistently strengthen law and regulation of electronic commerce.

(g) Pay attention to the network information policy and law in line with the world standard.

(h) Lay stress on complementary role of law and policy, and also establishment and improvement of network information law and policy system.

(i) Persist in independent legislation, making full use of actual law and regulation, regulating and improving previous existing law, integrating with establishing new regulation and industrial association making rules.

\section{Construction of Japanese Network Information Law and Policy System and Its Implication for China}

With the rapid development of information technology, a series of network information law and regulations have been successively released that involve domain name management, network information safety, computer software and E-Commerce. This shows that the government has pay attention to the construction of law and policy of network information resource management. But there still existed many problems to be solved. The construction and development of Japan's information resource policy and regulation will undoubtedly provide help suggestions.

(a) Strengthen the studies on basic theory of network information law and policy based upon our own situation. The Information Work Leading Group of the State Council and Cyberspace Administration of China have been set up so as to provide helpful management environment for the research of information law and policy. The institution of information law under China law society was founded in 2002. Thereafter some information law institutions are founded successively. Information and law institute centre is established in Beijing University of Posts and Telecommunication. Information and network law research room is established in law research institute of the Chinese academy of social sciences. The information resource research centre is also established in Wuhan University that undertakes great research task of "national information law and policy system". The research of information law and policy is common in China and produce many research results. Our country should set up special information law and policy committee that conducts various research efforts to strengthen basic theory study on the emerged problems in information resource 
management practice in China and produce more results of great theoretical and practical significance, for example research report and investigation report. Furthermore it should give suggestion for construction of information resource management law and policy.

(b) Lay emphasis on guidance of network information resource law and policy to information technology. China's 12-year Plan for Scientific and Technological Development was made in 1956. Schema about Development of Scientific and Technological Information was issued in 1958. National Science and Technology Information Development Policy (blue book) was published in late 90' s. It can be said that study of technical information law and policy is the beginning and concern. Furthermore our country publishes series of supporting laws and regulations such as Regulations for Computer Software Protection, Copyright Law, Telecommunications Regulations of PRC that promote the development and application of new technology. The Draft Cybersecurity Law has been put forward to the NPC for deliberation in 2015 as well as to defend our cyberspace. The competition of information technology has been changed into competition in field of information technology standard in new stage. The developed countries actively participate in formulating the international standards and continuously transforming their national standards into international standards, therefore leading the international standardization and improving competitiveness of information technology. So our country has also issued many standardized guiding technical documents and network information technology standard based on international standard.

However, the law and policy system of network information resource management is not perfect, and the standard is still of government-sponsored publishing. The standard and law have not established international collaborative mechanism. It greatly hinders the process and capability of information technology to participate international competition. The author thinks we should draw on foreign advanced experience, strengthen development, application and standardized construction, improve the perfection and collaboration of management law and policy of network information resource, promote development of network information technology and occupy commanding elevation of international information technology.

(c) Establish complete network information resource law and policy in accordance with international practice. The network information law and policy system has not formulated into complete architecture. For example, there is not one programmatic policy as Japan to indicate the development objective of informatization in China. There is also not a scientific law and policy system to ensure the existence and development of network and E-Commerce as sun-rising industry. Some urgent problems in network have no corresponding law to regulate them. In addition, the law administration in information construction is weak and the shortage of network talent is common. This enormously restricts the development of information resource management activity.

Fortunately, new progress has been made in the research of network information resource management policies and regulations. Dr. Ke Ping of Nankai University put forward the eight direction of our country's information policy, i. e. national characteristics of information strategy, solution of domestic problem of "digital divide", policy of developing information industry, policy of developing E-commerce, policy of developing E-commerce and industrial informatization, policy of developing national information technology, promoting coordinative development of information industry and market and building up law and policy system of network information. Dr. Zhou 
Qing-Shan of Beijing University divides information legal system into eight section, i. e. government information legislation, business information legislation, public information legislation, personal information legislation, law of information property, mass-communication legislation, law of information network and international information legislation. Otherwise many scholars have discussed them from different angles. I think improving the construction of network information law and policy system should study the deficiency of present system in view of the existed problem, draw on results of theory research, pay attention to the structure perfection of law and policy system along with the hierarchical rationality, attach great important on the coordination and complementarity of law and regulations and also the compatibility with international protocol and regulation.

(d) The legal and policy system of network information concerns many aspects and involves various disciplines; even the military has clear policy planning in Japan. The 2010 National Defense Program Guidelines, the JSDF's current guiding document, established the Self-Defense Forces as a component of the national response to cyber-attacks, with the resources put towards the SDF C4 (Command, Control, Communication \& Computers) systems command being used to protect the public alongside an independent NISC. Implementation of a full scan by anti-virus software at least once a week. 24/7 year-round monitoring to ensure that no information that should be protected is leaked outside the company. Preservation for at least three months of records of access to information that should be protected [4]. These measures make us to mobilize diverse forces to participate the promotion and practice of network security policy and law. Meanwhile we should improve the transparency of network legal system and policy and so on.

\section{Conclusions}

In summary, based on our country's practice, attaching great importance on theory research of network information resource law and policy, emphasizing the leading and developing effects of law and policy, paying attention to self-construction of law and policy system and highlighting the strategic significance of law and policy construction of network information safety are the best implication which the construction of network information law and policy of Japan and other west developed country supply to us.

\section{References}

[1] Luo Guang-san, He Ruyun. A probe to the intellectual property right in the digital library construction (in Chinese), Journal of Library. No. 5 (2002) : 58-60.

[2] Zhong Hua. Law, policy and thinking of network information safety (in Chinese), China Information Security. No. 5 (2001): 48-51.

[3] Nakamura. The role of government in network society: perspective of Japan's information policy (in Chinese), China Opening Herald. No. 7 (2001): 17-18.

[4] Japan Government. To Create Agency Similar To NSA For Internet Eavesdropping, https://traxarmstrong.com/japan-to-create-agency-similar-to-nsa-for-internet-eavesdro pping/\#gsc.tab $=0$. 